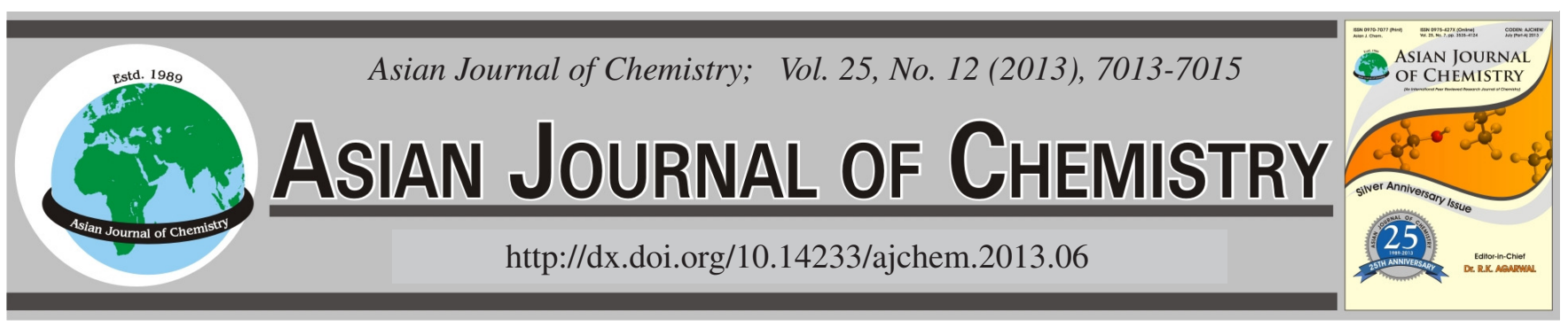

\title{
Pre-Irradiation of Boric Acid Solutions in a Research Reactor $\dagger$
}

Hee-Jung Im ${ }^{1, *}$, Sung Tack Hong ${ }^{2}$, Gee-Yang Han ${ }^{2}, \mathrm{Ke}_{\mathrm{Chon}} \mathrm{ChOI}^{1}$, Jei-Won Yeon ${ }^{1}$, Hung-Woo Kim ${ }^{1}$, Man-Soon $\mathrm{CHO}^{3}$, Kyung-Duk $\mathrm{JAng}^{4}$, Ul Jae Park ${ }^{4}$, SAng-Jun Park ${ }^{3}$ and Hoan-Sung Jung ${ }^{2}$

\begin{abstract}
${ }^{1}$ Nuclear Chemistry Research Division, Korea Atomic Energy Research Institute,150 Deokjin-dong, Yuseong-gu, Daejeon 305-353, Republic of Korea

${ }^{2}$ HANARO Management Division, Korea Atomic Energy Research Institute, 150 Deokjin-dong, Yuseong-gu, Daejeon 305-353, Republic of Korea ${ }^{3}$ Neutron Utilization Technology Development Division, Korea Atomic Energy Research Institute, 150 Deokjin-dong, Yuseong-gu, Daejeon 305-353, Republic of Korea

${ }^{4}$ Radioisotope Utilization Technology Development Division, Korea Atomic Energy Research Institute, 150 Deokjin-dong, Yuseong-gu, Daejeon 305-353, Republic of Korea
\end{abstract}

*Corresponding author: Fax: +82 42 8688148; Email: imhj@kaeri.re.kr

AJC-13628

\begin{abstract}
Interpretation of coolant chemistry performance is very important because the performance can be an effective indicator in monitoring operational safety of nuclear power plants. To determine the radiolysis degree of boric acid solutions, which are added for neutron absorption to control core reactivity during the nuclear power plant operation, and understand the physico-chemical nature of the process under neutron irradiation in a nuclear reactor, the preparation and safety check points for the irradiation of boric acid solutions are discussed.
\end{abstract}

Key Words: Boric acid solution, Neutron absorber, Thermal neutrons, Radiation irradiation process, Radiolysis.

\section{INTRODUCTION}

Nuclear reactions of neutron absorbers such as ${ }^{10} \mathrm{~B}$ or ${ }^{6} \mathrm{Li}$ in solid materials with thermal neutrons have been widely studied, and their applications are quite broad ${ }^{1,2}$. To our best of knowledge, the thermal neutron irradiation of water samples containing neutron absorbers has not been published except for a paper reporting the experimental data obtained at high temperatures ${ }^{3}$. However, irradiation ${ }^{4}$ or simulations ${ }^{5,6}$ of water and voluminous liquid samples with fast neutrons and $\gamma$-rays are frequently discussed in some published papers.

Several water samples containing ${ }^{10} \mathrm{~B}$-enriched boric acid and natural and ${ }^{10} \mathrm{~B}$-enriched mixed boric acids in the range of 0 to $2000 \mu \mathrm{g} / \mathrm{mL}$ for the function of ${ }^{10} \mathrm{~B}$ concentration, were irradiated to study the radiolysis of the cooling water containing boric acid. The concentration of natural boron in the primary coolant of pressurized water reactors (PWRs) is known to start at $1500 \mu \mathrm{g} / \mathrm{mL}$, and boric acid is used for the purpose of nuclear reaction control. Herein, we introduce a preparation process for the irradiation of boric acid solutions.

\section{EXPERIMENTAL}

Different amounts of natural boric acid $\left(\mathrm{H}_{3} \mathrm{BO}_{3}, 99.999 \%\right.$, Aldrich) and ${ }^{10} \mathrm{~B}$-enriched boric acid $\left(\mathrm{H}_{3}{ }^{10} \mathrm{BO}_{3}, 99 \%\right.$, Aldrich $)$ were dissolved in deionized water at various sample concentrations. Fig. 1 showed that the ultra-clean quartz tubes (diameter: $8 \mathrm{~mm}$ and thickness: $2 \mathrm{~mm}$ ) were cut and sealed at one edge using hydrogen gas. Next, 1 or $2 \mathrm{~mL}$ of each prepared boric acid solution was poured into one edge of the sealed tubes and vacuumed to $1 \times 10^{-4}$ torr in liquid nitrogen. The other edges of the tubes containing frozen sample solutions were immediately sealed to make bullet-shaped quartz ampoules (diameter: $8 \mathrm{~mm}$, height: $55 \mathrm{~mm}$ and thickness: 2 $\mathrm{mm})$. The sealed ampoules were placed in specially manufactured aluminum (Al) inner capsules and then in radio isotope (RI) target aluminium outer capsules. Both capsules were made of aluminium to avoid an overly strong activation and overly long radioactive decays. In addition, the rooms between the ampoule and the aluminium inner and outer capsules were filled with aluminium foil uniformly for the distribution of heat produced from irradiation.

Several $\mathrm{Co}$ and $\mathrm{Zr}$ foils were placed together with the sealed ampoules for accurate neutron counting. The samples were irradiated for 60, 120 and $240 \mathrm{~min}$ in a IP04 hole (thermal neutron flux : $2.81 \times 10^{13} \mathrm{n} \mathrm{cm}^{-2} \mathrm{sec}^{-1}$; fast neutron flux: $\left.7.46 \times 10^{9} \mathrm{n} \mathrm{cm}^{-2} \mathrm{sec}^{-1}\right)$ of the high-flux advanced neutron application reactor (HANARO) at the Korea Atomic Energy Research Institute (KAERI) ${ }^{7}$.

$†$ Presented to the 4th International Symposium on Applications of Chemical and Analytical Technologies in Nuclear Industries, Daejeon, Korea 

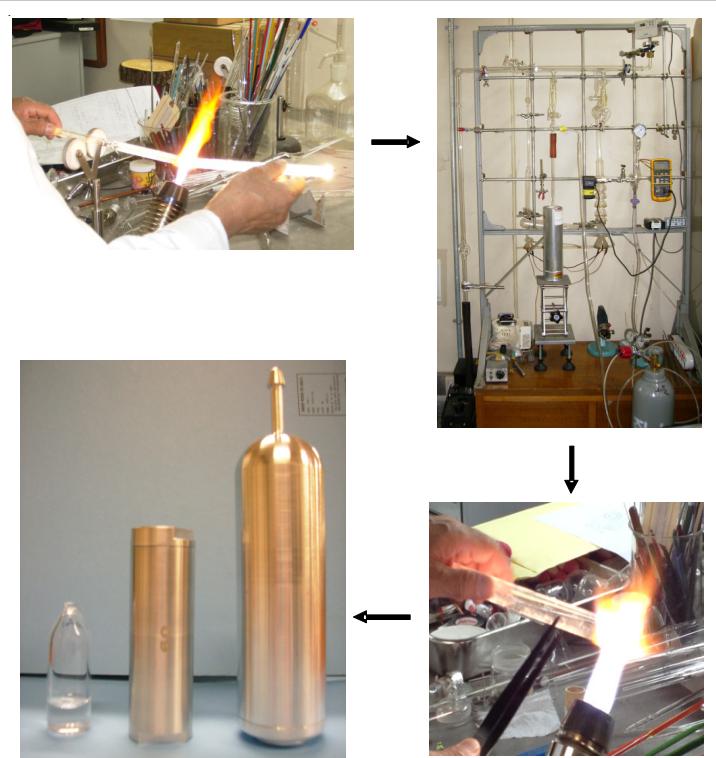

Fig. 1. Photos of quartz ampoule preparation and a complete quartz ampoule containing a boric acid solution and inner and outer $\mathrm{Al}$ capsules

\section{RESULTS AND DISCUSSION}

When solid samples are irradiated with neutrons, it is relatively easy to control the physical phenomena caused by the irradiation. However, for solution samples, there is a certain limitation in the irradiation amount because of the difficulty in temperature control owing to an increase in pressure and heat produced inside of the containers by the irradiation. Therefore, some calculations were performed in advance of the sample solution irradiations for stability- and safety-related checks.
Heat generated from a boric acid solution, a container filling material (aluminium foil) and containers including a quartz ampoule, an aluminium inner capsule and an radio isotope target aluminium capsule during irradiation in the IP04 hole was calculated using a Monte Carlo N-particle Transport Code, Version $5^{8}$. The experimental setup and parameters used for the calculations are shown in Fig. 2 and Table-1 (a). Here, the maximum ${ }^{10} \mathrm{~B}$ concentration and maximum volume of a boric acid solution were chosen for the calculation.

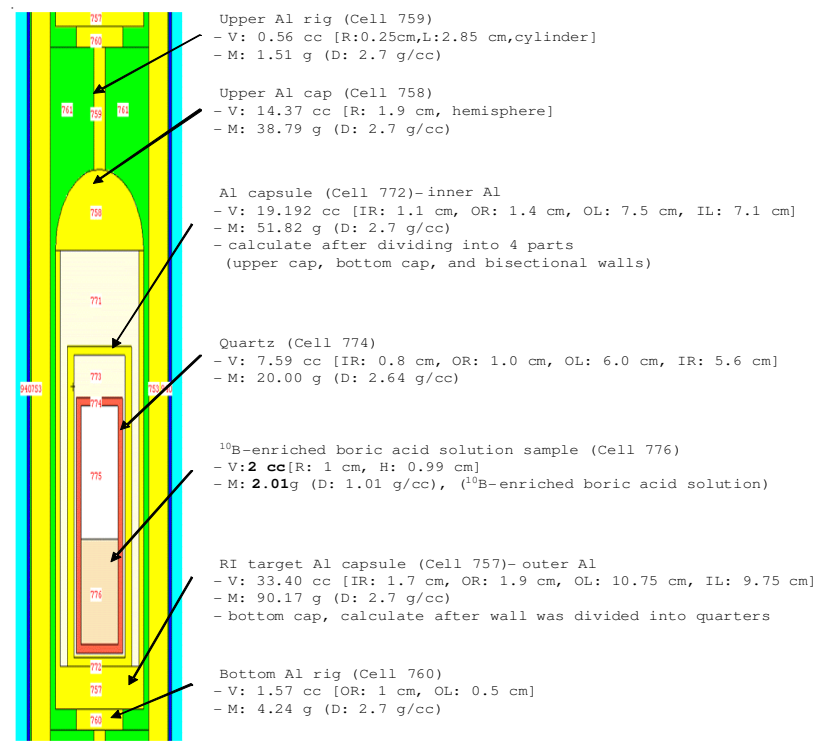

Fig. 2. Schematic diagram of the irradiation experimental setup (V: volume, $\mathrm{R}$ : radius, L: length, M: mass, D: density, IR: inner radius, OR: outer radius, IL: inner length, OL: outer length and H: height; the numbers were rounded to two decimal points.)

TABLE-1

(a) PARAMETERS FOR THE HEAT CALCULATION MCNP CODE AND (b) NEUTRON AND (c) $\gamma$-HEATS CALCULATED USING THE MCNP CODE

\begin{tabular}{|c|c|c|c|c|c|c|}
\hline \multirow[t]{2}{*}{ (a) } & \multicolumn{6}{|c|}{$\begin{array}{l}\text { For a } 2000 \mu \mathrm{g} / \mathrm{mL}\left[{ }^{10} \mathrm{~B}\right] \text { from }{ }^{10} \mathrm{~B} \text {-enriched boric acid solution } 2 \mathrm{~mL} \text {, } \\
\left.\text { Density of } \mathrm{H}_{3}{ }^{10} \mathrm{BO} \mathrm{O}_{3} \text { solution (for the } 2000 \mu \mathrm{g} / \mathrm{mL}\left[{ }^{10} \mathrm{~B}\right]\right)=1.00534 \mathrm{~g} / \mathrm{mL} \\
2000 \mu \mathrm{g} / \mathrm{mL}\left[{ }^{10} \mathrm{~B}\right] \text { solution }=2000 \mu \mathrm{g}{ }^{10} \mathrm{~B} / 1.005 \mathrm{~g} \text { solution } \\
\qquad \begin{array}{r}=4000 \mu \mathrm{g}{ }^{10} \mathrm{~B} / 2.01 \mathrm{~g} \text { solution } \\
\text { In other words, } 4000 \mu \mathrm{g}{ }^{10} \mathrm{~B}=24416 \mu \mathrm{g}\left(0.024416 \mathrm{~g} \text { ) of } \mathrm{H}_{3}{ }^{10} \mathrm{BO}_{3}\right.\end{array} \\
\text { Mass of } \mathrm{H}_{2} \mathrm{O}=2.01068 \mathrm{~g}-0.024416 \mathrm{~g}=1.9863 \mathrm{~g}\end{array}$} \\
\hline & & & & \multicolumn{2}{|c|}{$\begin{array}{lll} & \text { Each atomic mass in the solution } \\
00244 & 0.0012 & \text { H }\end{array}$} & \\
\hline \multirow[t]{3}{*}{$\mathrm{H}_{3}{ }^{10} \mathrm{BO}_{3}$} & 0.0244 & $\mathrm{H}(3 / 61)$ & 0.0012 & $\mathrm{H}$ & 0.22347368 & \\
\hline & & ${ }^{10} \mathrm{~B}(10 / 61)$ & 0.004 & B & 0.004 & \\
\hline & & $\mathrm{O}(48 / 61)$ & 0.0192 & $\mathrm{O}$ & 1.7832363 & \\
\hline \multirow{2}{*}{$\mathrm{H}_{2} \mathrm{O}$} & 1.9863 & $\mathrm{H}(2 / 18)$ & 0.22226 & & & \\
\hline & & $\mathrm{O}(16 / 18)$ & 1.76404 & & & \\
\hline \multicolumn{7}{|c|}{ Neutron heat $(\mathrm{CAR}=450$, library $60 \mathrm{c})$} \\
\hline & Volume & Density (g/cc) & Mass (g) & Heat $(\mathrm{W} / \mathrm{g})$ & FSD & Total heat $(\mathrm{W})$ \\
\hline $\mathrm{H}_{3}{ }^{10} \mathrm{BO}_{3}$ solution & 2.00000 & 1.01 & 2.0200 & $7.9214 \mathrm{E}+00$ & 0.0242 & 16.001 \\
\hline Quartz & 7.59000 & 2.635 & 19.9997 & 2.6758E-04 & 0.2652 & 0.005 \\
\hline Inner Al1 & 1.23150 & 2.7 & 3.3251 & 2.2713E-04 & 0.2891 & 0.001 \\
\hline Inner Al2 & 8.36450 & 2.7 & 22.5842 & $1.2010 \mathrm{E}-04$ & 0.1720 & 0.003 \\
\hline Inner $\mathrm{Al} 3$ & 8.36450 & 2.7 & 22.5842 & $1.6673 \mathrm{E}-04$ & 0.1831 & 0.004 \\
\hline Inner Al4 & 1.23150 & 2.7 & 3.3251 & $1.2176 \mathrm{E}-04$ & 0.2224 & 0.000 \\
\hline Outer Al1 & 22.05398 & 2.7 & 59.5457 & 2.0904E-04 & 0.1074 & 0.012 \\
\hline Outer Al2 & 11.34115 & 2.7 & 30.6211 & 2.8007E-04 & 0.3772 & 0.009 \\
\hline Upper rig & 0.55960 & 2.7 & 1.5109 & 2.4037E-04 & 0.5669 & 0.000 \\
\hline Upper cap & 14.36546 & 2.7 & 38.7867 & $2.7066 \mathrm{E}-04$ & 0.3132 & 0.010 \\
\hline Bottom rig & 1.57080 & 2.7 & 4.2412 & $9.1282 \mathrm{E}-05$ & 0.2752 & 0.000 \\
\hline$* \mathrm{Al}$ foil $(3 \%)$ & 8.13987 & 0.081 & 0.6593 & $1.3829 \mathrm{E}-04$ & 0.1471 & 0.000 \\
\hline \multirow[t]{3}{*}{$* * \mathrm{Al}$ foil $(8 \%)$} & 42.34081 & 0.216 & 9.1456 & 2.3903E-04 & 0.1634 & 0.002 \\
\hline & & & \multicolumn{3}{|c|}{ Total } & 16.049 \\
\hline & & Thermal fl & $625 \mathrm{ev})$ & $5.407 \mathrm{E}+13$ & 0.0234 & \\
\hline
\end{tabular}




\begin{tabular}{|c|c|c|c|c|c|}
\hline \multirow[t]{2}{*}{ (c) } & \multicolumn{4}{|c|}{$\gamma$-Heat $(\mathrm{CAR}=450)$} & \multirow[b]{2}{*}{$\times 1.5$} \\
\hline & Mass (g) & Heat $(\mathrm{W} / \mathrm{g})$ & FSD & Total heat (W) (prompt $\gamma)$ & \\
\hline $\mathrm{H}_{3}{ }^{10} \mathrm{BO}_{3}$ solution & 2.0200 & $1.5271 \mathrm{E}-01$ & 0.0616 & 0.308 & 0.463 \\
\hline Quartz & 19.9997 & $1.1921 \mathrm{E}-01$ & 0.0325 & 2.384 & 3.576 \\
\hline Inner Al1 & 3.3251 & 1. $1054 \mathrm{E}-01$ & 0.0693 & 0.368 & 0.551 \\
\hline Inner A12 & 22.5842 & $1.1695 \mathrm{E}-01$ & 0.0330 & 2.641 & 3.962 \\
\hline Inner $\mathrm{Al} 3$ & 22.5842 & $1.2120 \mathrm{E}-01$ & 0.0343 & 2.737 & 4.106 \\
\hline Inner Al4 & 3.3251 & $1.2265 \mathrm{E}-01$ & 0.0651 & 0.408 & 0.612 \\
\hline Outer Al1 & 59.5457 & 1. $1924 \mathrm{E}-01$ & 0.0193 & 7.100 & 10.651 \\
\hline Outer A12 & 30.6211 & $1.2555 \mathrm{E}-01$ & 0.0367 & 3.845 & 5.767 \\
\hline Upper rig & 1.5109 & $1.2245 \mathrm{E}-01$ & 0.0931 & 0.185 & 0.278 \\
\hline Upper cap & 38.7867 & $1.2140 \mathrm{E}-01$ & 0.0348 & 4.709 & 7.063 \\
\hline Bottom rig & 4.2412 & $1.4150 \mathrm{E}-01$ & 0.0651 & 0.600 & 0.900 \\
\hline$* \mathrm{Al}$ foil $(3 \%)$ & 0.6593 & $1.1230 \mathrm{E}-01$ & 0.0338 & 0.074 & 0.111 \\
\hline \multirow[t]{2}{*}{$* * \mathrm{Al}$ foil $(8 \%)$} & 9.1456 & $1.1448 \mathrm{E}-01$ & 0.0208 & 1.047 & 1.571 \\
\hline & & & Total & 26.406 & 39.609 \\
\hline
\end{tabular}

As shown in Table-1, the estimated maximum total neutron heat (Table-1b) and $\gamma$-heat (Table-1c) produced from the irradiation in the IP04 hole are 16.049 and 39.609 watts (W), respectively. In Table-1c, the total $\gamma$-heat obtained is 1.5 times the total prompt $\gamma$-heat, because delayed $\gamma$-heat is considered to be approximately $50 \%$ of calculated prompt $\gamma$-heat of $26.406 \mathrm{~W}$.

The temperatures of the sample solution and the surrounding materials during the irradiation were also computed by applying the obtained heat values in Table-1 to a one-dimensional heat transfer calculation code of GENGTC ${ }^{9}$. In this calculation, there is an assumption that the samples in the IP04 hole are cooled by natural convection, not by forced convection and the temperature of the cooling water is $35^{\circ} \mathrm{C}$. For the heat transfer ratio from natural convection, the surface target heat transfer coefficient was estimated using the Churchill-Chu correlation for a straight wall or cylinder. The computed temperatures were all below $70^{\circ} \mathrm{C}$, as shown in Table-2.

TABLE-2

CALCULATED TEMPERATURE DISTRIBUTION BY THE IRRADIATION OF THE BORIC ACID SOLUTION AND THE SURROUNDING MATERIALS USING GENGTC CODE

\begin{tabular}{lc}
\hline $\begin{array}{l}\text { Heat transfer coefficient at the surface of the outer } \\
\text { capsule }\end{array}$ & $\begin{array}{c}0.0835 \\
\left(\mathrm{~W} / \mathrm{cm}^{2}-{ }^{\circ} \mathrm{C}\right)\end{array}$ \\
\hline Temperature of the outer capsule & 60.6 \\
$\mathrm{Al}$ foil $(8 \%)$ in cell 771 & 60.8 \\
Temperature of the inner capsule & 61.1 \\
$\mathrm{Al}$ foil (3\%) in cell 773 & 61.5 \\
Temperature of quartz $\left(\mathrm{SiO}_{2}\right)$ & 61.6 \\
Target temperature of the $\mathrm{H}_{3} \mathrm{BO}_{3}$ solution & 66.96 \\
\hline
\end{tabular}

A fast neutron is around as small as $0.0265 \%$ of the total neutron flux in the IP04 hole. (As a reference, for commercial nuclear reactors such as PWRs, the fast neutron flux is generally $7.5 \times 10^{14} \mathrm{n} \mathrm{cm}^{-2} \mathrm{sec}^{-1}$ and the thermal neutron flux is 2.5 $\left.\times 10^{14} \mathrm{n} \mathrm{cm}^{-2} \mathrm{sec}^{-1}\right)^{3}$. The thermal neutron flux in our experimental condition is much higher than the fast neuron flux. In addition, it is known that radiolysis gas molecular products of pure water through thermal neutron irradiation are negligible. For the current analysis, we are more interested in the thermal neutron effect on the boric acid solution radiolysis.
To determine the degree of radiolysis of boric acid solutions under thermal neutron irradiation, the concentrations of the produced products and diminished ${ }^{10} \mathrm{~B}$ will be discussed further in a sequence of experiments and research papers.

\section{Conclusion}

Prior to boric acid solution irradiation, a careful sample preparation and some calculations were performed for stabilityand safety-related checks. The estimated maximum total neutron heat and $\gamma$-heat were 16.049 and 39.609 watts (W), respectively, and the computed temperatures of the boric acid solution and surrounding materials were all below $70^{\circ} \mathrm{C}$, which is stable enough to be irradiated in the IP04 hole. It is ready for an analysis of the irradiated samples to discuss the radiolysis of boric acid solutions quantitatively based on our successful sample preparation and safety check results.

\section{ACKNOWLEDGEMENTS}

This work was supported by the Nuclear Research and Development Program through the National Research Foundation of Korea funded by the Ministry of Education, Science and Technology.

\section{REFERENCES}

1. H.-J. Im, S. Saengkerdsub, A.C. Stephan, M.D. Pawel, D.E. Holcomb and S. Dai, Adv. Mater., 16, 1757 (2004).

2. H.-J. Im, C. Willis, A.C. Stephan, M.D. Pawel, S. Saengkerdsub and S. Dai, Appl. Phys. Lett., 84, 2448 (2004).

3. B. Pastina, J. Isabey and B. Hickel, J. Nucl. Mater., 264, 309 (1999).

4. J.I. Kim, H. Stark and I. Fiedler, Nucl. Instrum. Methods, 177, 557 (1980).

5. G.R. Sunaryo, Y. Katsumura and K. Ishigure, Radiat. Phys. Chem., 45, 703 (1995).

6. Y. Katsumura, G. Sunaryo, D. Hiroishi and K. Ishigure, Prog. Nucl. Energy, 32, 113 (1998).

7. K.N. Choo, B.G. Kim, M.S. Cho, Y.K. Kim and J.J. Ha, IEEE Trans. Nucl. Sci., 57, 2642 (2010).

8. LANL, MCNP-A General Monte Carlo N-particle Transport Code Version 5 (2003).

9. H. Someya, T. Kobayashi, M. Niimi, T. Hoshiva and Y. Harayama, GENGTC-JB: A Computer Program, JAERI-M87-148 (1987). 